\title{
The expanding role of defined contribution plans in the USA: Benefits, restrictions and risks
}

Received: 12th February, 2004

\section{Ramon P. DeGennaro}

is the SunTrust Professor of Finance at The University of Tennessee, Knoxville, Tennessee, and Visiting Scholar, Federal Reserve Bank of Atlanta, Atlanta, Georgia. His home page at The University of Tennessee is

http://www.bus.utk.edu/finance/fac_staff/DeGennaro/degenn.htm, and many of his papers are available from SSRN at http://ssrn.com/author=017288.

\section{Deborah L. Murphy}

is Associate Professor of Finance and Reagan Scholar at The University of Tennessee, Knoxville. Her research interests include investments and corporate misconduct. She has published in journals such as the Journal of Portfolio Management, Financial Analysts Journal and Journal of Business Ethics.

\begin{abstract}
As questions regarding the future of the US social security system (the nation's public retirement plan) continue to surface, interest in employer-sponsored retirement plans as well as other retirement investment options increases. But the restrictions and rules associated with various defined benefit plans such as $401(\mathrm{k})$, 403(b) and 457 plans can be confusing, and these plans are not without risks. This paper explores these plans and explains the need to view retirement savings in a total portfolio context.
\end{abstract}

Keywords: asset; allocation; savings; taxes; pension; retirement

Ramon P. DeGennaro University of Tennessee, Knoxville, Department of Finance, 423 Stokely Management Center, Knoxville, TN 37996, USA.

Tel: +1 865974 1726;

Fax: +1 865974 1716;

e-mail: rdegenn@utk.edu

\section{Introduction}

In the USA retirement savings are trending towards defined contribution (DC) plans rather than defined benefit (DB) plans. Historically, DB plans have been designed to promise a specified stream of benefits at retirement with the employer bearing the investment risk. In general, if the investment returns are poor, the employer must contribute extra funds to cover the shortfall needed to meet the cash flow obligations of the plan. By contrast, DC plans give employees a way to contribute a portion of their pre-tax income to a retirement savings account while giving them some discretion over the way the funds are invested. However, with DC plans, employees bear 100 per cent of the investment risk of the portfolio. Currently, the three most popular types of DC plans in the USA are $401(\mathrm{k})$ plans (offered by private employers such as publicly traded companies), 403(b) plans (offered by non-profit entities such as universities) and 457 plans (offered by state and local governments). Because each plan is governed by somewhat 
Table 1: Percentage change in the maximum annual contributions permitted ${ }^{\mathrm{a}}$

\begin{tabular}{lcl}
\hline Year & Maximum deferral limits $\mathbf{( \$ ) ^ { \mathbf { b } }}$ & Percentage change in limits $(\%)$ \\
\hline 1987 & 7,000 & - \\
1988 & 7,313 & 4.47 \\
1989 & 7,627 & 4.29 \\
1990 & 7,979 & 4.62 \\
1991 & 8,475 & 6.22 \\
1992 & 8,728 & 2.99 \\
1993 & 8,994 & 3.05 \\
1994 & 9,240 & 2.74 \\
1995 & 9,240 & 0.00 \\
1996 & 9,500 & 2.81 \\
1997 & 9,500 & 0.00 \\
1998 & 10,000 & 5.26 \\
1999 & 10,000 & 0.00 \\
2000 & 10,500 & 5.00 \\
2001 & 10,500 & 0.00 \\
2002 & 11,000 & 4.76 \\
2003 & 12,000 & 9.09 \\
2004 & 13,000 & 8.33 \\
2005 & 14,000 & 7.69 \\
2006 & $15,000^{c}$ & 7.14 \\
\hline
\end{tabular}

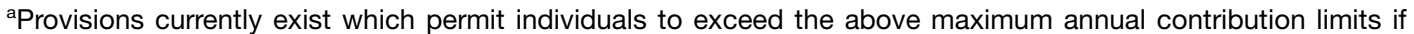
they either were ineligible to contribute or did not contribute the maximum allowed in previous years.

bSource: The Hay Benefits Reference Guide.

${ }^{\mathrm{C}}$ After 2006, the maximum annual contributions will be indexed to inflation in $\$ 500$ increments. The provisions of HR 1836 remain in effect until 31st December, 2010, at which time they revert to prior law unless further action is taken by the US President and Congress.

different rules, the primary focus of our discussion will be 401(k) plans and Roth individual retirement accounts (IRAs).

\section{History and mechanics}

Laws governing the establishment of 401(k) plans came into effect in the USA on 1st January, 1980, through a provision of The Revenue Act of 1978 known as Internal Revenue Code s. 401(k). Rapid growth in $401(\mathrm{k})$ plans did not occur until 1981, when the US Internal Revenue Service sanctioned the use of pre-tax salary contributions by employees. ${ }^{1}$ According to The Hay Benefits Reference Guide, maximum annual deferred limits to $401(\mathrm{k})$ plans have ranged from $\$ 7,000$ in 1987 to $\$ 11,000$ in 2002 (see Table 1). With the passage of US House Resolution 1836, Economic Growth and Tax Relief Reconciliation Act of 2001 (HR 1836), however, elective annual contribution limits will increase by $\$ 1,000$ per year to 2006 , reaching a maximum of $\$ 15,000$. $^{2}$

The importance of the newly legislated and substantial increases in the maximum elected contributions (a 9.09 per cent increase from 2002 to 2003) is evident when one considers how 401(k) plans work. Essentially, one person uses an employer sponsored investment vehicle to shift a tax liability to a different (and presumably more favourable) future time period. Table 2 shows the events that occur for an employee who earns income in 2004 and retires in 2044.

This is essentially tax arbitrage through time. Viewed this way, it is somewhat comparable to shifting the tax liability to a different person with a lower marginal tax rate in the same time period. For example, owners and managers of companies can hire their children to 
Table 2: Timeline of events occurring for an employee earning income in 2004 and retiring in 2044

\begin{tabular}{llll}
\hline & & $\begin{array}{c}\text { Year } \\
\text { 2004-2044 }\end{array}$ & 2044 \\
\hline \multirow{2}{*}{ Event } & $\begin{array}{l}\text { Employee } \\
\text { earns income } \\
\text { (no taxes } \\
\text { on plan contributions) }\end{array}$ & $\begin{array}{l}\text { Investment } \\
\text { earnings accrue } \\
\text { without taxes }\end{array}$ & $\begin{array}{l}\text { Principal } \\
\text { and earnings } \\
\text { withdrawn (taxes paid) }\end{array}$ \\
& & & \\
\hline
\end{tabular}

mow the lawn at a property they rent to others, or hire a retired parent for bookkeeping or receptionist work. The employer deducts the wage expense, saving the marginal corporate tax rate, while the child or parent pays income tax at the lower rate applicable to low-income individuals. Hence, the net tax savings are available for the company and the employee to share.

While differences exist between 401(k) plans, 403(b) plans, 457 plans, and Roth IRAs, the premise behind each retirement account is essentially the same. ${ }^{3}$ All of the plans are designed to promote personal savings for retirement. 401(k), 403(b), and 457 plans allow individuals to defer current income taxes by deducting pre-tax earned income through payroll deduction. Taxes are paid when the funds are withdrawn from the plan, presumably at retirement when one's personal income tax rate is expected to be lower. The precise details of these three sponsored plans are unique to the employer, and there are differences among them. For example, an employer offering a $401(\mathrm{k})$ plan can define the eligibility of an employee to participate in the plan and set a minimum tenure of employment. In addition, employers have considerable discretion regarding the plan features such as whether they will match employee contributions or the extent to which contributions will be matched (say $\$ 1$ for $\$ 1$ or $\$ 0.50$ per $\$ 1)$. By law, employee contributions are fully vested (that is, the employee secures full ownership) at the time each contribution to the plan is made, but employers can delay vesting of their matching contribution for up to seven years. ${ }^{4}$

While current legislation has eliminated many of the differences between 401(k), 403(b) and 457 plans, regulatory differences still remain. For example, unlike 401(k) plans, which permit purchases of individual securities such as common stock, individual security purchases are prohibited with 403(b) plans. Contributions to 403(b) plans can only be invested in annuities or mutual funds. This can prove problematic when an individual changes employment from the public to the private sector. Prior to 2002, federal law prohibited the rollover of funds into a 401(k) plan from either 403(b) or 457 plans (and vice versa). However, under HR 1836, new 'portability' rules have been enacted which allow monies invested in 403(b) plans or 457 annuity plans to be rolled over into an employer-sponsored 401(k) plan. The ability to do so, however, is at the full discretion of the employer. Likewise, rollovers into 403(b) and 457 plans from an employer-sponsored $401(\mathrm{k})$ plan are at the discretion of the plan sponsor. ${ }^{5}$

While 401(k) plans are strictly employer sponsored and cannot be established by an individual, a possible alternative, a Roth IRA, was established in 1988 as a result of the Taxpayer Relief Act of $1997 .{ }^{6}$ Roth IRAs differ from 401(k), 403(b) and 457 DC plans in two fundamental ways. First, annual 
contributions are made using after-tax dollars versus pre-tax dollars. Secondly, unlike the tax liability that is incurred when monies are withdrawn at retirement from a pre-tax plan, no tax liability is incurred when funds are withdrawn from a Roth IRA if certain criteria are met. Essentially, taxes are paid 'up-front' with a Roth IRA and at the 'back-end' with 401(k), 403(b) and 457 plans. One benefit of a Roth IRA is that no minimum or maximum age limits are imposed on the contributor. Since the only caveat is that the contributor must have earned income, essentially a ten-year-old child who mows lawns during the summer can contribute to a Roth IRA. Likewise, a 90-year-old individual, who works as a ranger at a golf course, can establish a Roth IRA. Another benefit of a Roth IRA is that minimum withdrawals are not required at age 70 -and-a-half. ${ }^{7}$ Since contributions to a Roth IRA are permitted even if an individual is contributing to an employer sponsored plan, many individuals may find it advantageous to coordinate their contributions to both a Roth IRA and, for example, a 401(k) plan.

There are certain restrictions and limitations associated with Roth IRAs. Annual contributions are limited to $\$ 3,000$ for participants until age 50 $(\$ 3,500$ after age 50$)$ and may be reduced or even eliminated depending on one's income level and federal income tax filing status. As an individual's modified adjusted gross income rises, the available annual contribution falls. The contribution limit also depends on the contributions made to other retirement plans. Recent legislation prohibits rolling over contributions made to a Roth IRA into either a 403(b) or a 457 plan. Rollovers into other DC plans such as a $401(\mathrm{k})$ plan are at the discretion of the plan's sponsor and strict accounting is required with respect to pre-tax and after-tax contributions. This detailed accounting requirement may effectively deter employers from permitting Roth rollovers.

The tax advantages associated with retirement savings accounts such as DC plans can be large. Equation 1 gives the terminal value of a fully taxable portfolio $\left(\mathrm{TV}_{\mathrm{T}}^{\mathrm{FT}}\right)$ worth $P_{0}$ before taxes at time $t=0$, assuming the portfolio earns a return of $r$ before taxes in each period, is taxed at an annual rate $\tau$, and the investment period is over a period of $\mathrm{T}$ years. Note that it is also assumed that the initial investment $\left(P_{0}\right)$ is taxed at a rate $\tau_{0}$. Equation 2 gives the terminal value of a similar investment in a portfolio allocated to a Roth account. The initial investment is taxed at the same rate as the taxable account and the before tax return is identical. However, the earnings on the investment are not taxed in the Roth IRA account.

Equation 3 gives the corresponding terminal value for an investment in a 401(k) account. Unlike the fully taxable account and the Roth account, the initial investment in a $401(\mathrm{k})$ plan escapes taxation initially, but monies are taxed when the funds are withdrawn at time $\mathrm{T}$.

$$
\begin{gathered}
\mathrm{TV}_{\mathrm{T}}^{\mathrm{FT}}=P_{0} \star\left(1-\tau_{0}\right)^{\star} \\
{\left[\left(1+\left(r^{\star}(1-\tau)\right)\right]^{\mathrm{T}}\right.} \\
\mathrm{TV}_{\mathrm{T}}^{\mathrm{Roth}}=P_{0} \star\left(1-\tau_{0}\right)^{\star}\left[(1+r)^{\mathrm{T}}\right. \\
\mathrm{TV}_{\mathrm{T}}^{401(\mathrm{k})}=P_{0}^{\star}(1+r)^{\mathrm{T}}\left(1-\tau_{\mathrm{T}}\right)
\end{gathered}
$$

While equations $1-3$ assume that the tax rate after time $t=0$ and the rate of return per period are constant, this simplifying assumption does not affect the intuition and results. Consider the following numerical example: suppose that the initial before-tax investment $\left(P_{0}\right)$ is $\$ 1,000$, the initial tax rate $\left(\tau_{0}\right)$ is 35 per 
cent, and the holding period $(\mathrm{T})$ is 40 years. If during those 40 years the return on the investment $(r)$ averages 8 per cent and the taxes at withdrawal $\left(\boldsymbol{\tau}_{\mathrm{T}}\right)$ are 30 per cent, then the terminal values are:

$$
\begin{aligned}
\mathrm{TV}_{\mathrm{T}}^{\mathrm{FT}} & =\$ 5,747 \\
\mathrm{TV}_{\mathrm{T}}^{\mathrm{R} \text { oth }} & =\$ 14,121 \\
\mathrm{TV}_{\mathrm{T}}^{401(\mathrm{k})} & =\$ 15,207 .
\end{aligned}
$$

In this case, the $401(\mathrm{k})$ plan yields the greatest terminal value $(\$ 15,207)$. If, however, the tax rate at withdrawal increases to 40 per cent, the Roth IRA becomes a more tax efficient investment with the corresponding terminal values of $\$ 4,240, \$ 14,121$, and $\$ 13,035$. This illustrates the critical importance of the relative tax rates. Krishnan and Lawrence develop the concept of a break-even terminal tax rate and show that if the expected tax rate at withdrawal is below this break-even rate, then the investor is better served by investing in a $401(\mathrm{k})$ plan. ${ }^{8}$ For terminal tax rates above break-even, the Roth IRA is better. Krishnan and Lawrence also show that this break-even rate is a decreasing function of the investment return, the investment horizon, and the tax rate on fully taxable investments. For all positive investment returns, however, the break-even rate is below the current tax rate. ${ }^{9}$

\section{Investment considerations}

In essence, a DC plan, such as a 401(k) plan, is simply a label attached to an investment that conveys the benefit of preferential tax treatment. As such, these plans are subject to the usual investment considerations, and determining the appropriate plan entails evaluating not only the above benefits and restrictions, but also the plan's risk and return characteristics. The recent retirement account losses experienced by the employees of companies such as Enron and WorldCom, Inc. serve to highlight the need for $401(\mathrm{k})$ plan contributors to view their retirement savings in a portfolio context. While the mathematics of optimal portfolio construction may be daunting, the basic principles are easily understood. Clearly, all investors want to earn the highest possible return. Greater returns, however, tend to come only by assuming greater risk. One way to reduce the risk associated with any financial investment, including 401(k) plans, is to diversify one's holdings.

Investment professionals and academic researchers have explored two forms of diversification - across assets and across time. Modern portfolio theory shows that, as long as assets are not perfectly correlated (that is, essentially not clones of each other), risk can be reduced by investing across different assets (hence the term, diversification across assets).

Diversification across assets is based on the concept that as long as assets are not perfectly correlated, the overall risk of one's portfolio is reduced since the price of stocks tends to change in a different way in response to changes in the economy. In addition, the risk associated with a specific firm (called 'firm-specific risk') will be minimised by diversifying across different assets. ${ }^{10}$ It is tempting to overlook the need to diversify within a 401(k) plan, especially if employee purchases of their employer's stock are matched by the employer. And while there is no one answer to how many stocks should be held in a portfolio, investment professionals typically suggest that the benefits of diversification across assets occur when one's portfolio consists of at least ten to 15 different stocks. ${ }^{11}$ As different assets are added to one's portfolio, the benefits associated with diversification increase. These increasing benefits occur at a decreasing rate, however. 
Another form of diversification sometimes advocated by investment professionals is diversification across time. Supporters of this form of diversification argue that the risk of one's investments can be reduced by buying an asset and holding it over a long period of time. Specifically, some advocate that for a long investment horizon (ten or more years), diversification across time can serve as an effective substitute for diversification across assets. However, research shows that while diversification across time serves to stabilise returns, it does not serve as a substitute for diversification across assets. ${ }^{12}$ One need only recall the recent losses experienced by the former employees of Enron and WorldCom, Inc. to understand the risk exposure associated with attempting to diversify solely across time. While many have heard the old adage, 'don't put all your eggs in one basket', perhaps the most frequently overlooked feature of 401(k) plans can be stated as 'don't put all your retirement savings into your employer's stock'.

The wide latitude which plan sponsors have in determining the specific details of a retirement plan, such as a $401(\mathrm{k})$ plan, introduces additional sources of risk. Although the US Department of Labor oversees employer sponsored 401(k) plans, unlike some DB plans, these plans are not guaranteed by any federal agency. As 401(k) plans are uninsured, employer-sponsored plans, the solvency and liquidity of the employer become extremely relevant. Some plan sponsors address this source of risk by naming an independent custodian to manage the plan. Another possible source of risk stems from restrictions placed on withdrawals from some 401(k) plans. While withdrawals are regulated under federal law, plan sponsors may impose additional restrictions. For example, employers often impose tenure constraints, especially if contributions are matched. Proper diversification can also be impeded by the limited investment choices offered by a plan sponsor. Some argue that limiting the choices available to $401(\mathrm{k})$ contributors simplifies the plan and lowers administration costs. This limitation may result in inadequate diversification, however, and the risk may be magnified in the case of plans funded by substantial holdings of a company's stock, as the contributor's wages are highly correlated with the return on the stock.

Most of these limitations reduce the advantages of a $401(\mathrm{k})$ plan from the perspective of both the employer and the employee, because the 401(k) plan provides a mechanism for the employer and the employee to minimise their combined tax burden. In the numerical examples above, the differences in values - all due to tax savings - between the terminal values of the $401(\mathrm{k})$ contribution and a fully taxable investment (per $\$ 1,000$ initial investment before taxes) is $\$ 9,460$ if the terminal tax rate is 30 per cent, and a still healthy $\$ 8,795$ if the terminal tax rate is 40 per cent. All else being equal, an employer who offers a $401(\mathrm{k})$ plan can reduce his wage expenses by the present value of that amount, while still leaving employees equally well off. Alternatively, the employer can increase his wages by that same amount, making his employees better off, while maintaining his present wealth. Labour market competition determines the ultimate sharing of the tax savings.

Viewed in this context, restrictions on investments limit this combined tax reduction. The most obvious example is the limitation on annual contributions: if limitations on contributions were relaxed, then the joint tax savings for the employer and employee could increase. Other restrictions, though, also limit the 
possible tax savings. First, restrictions on investment options or portability impose a penalty in the form of reduced diversification and liquidity, respectively. For example, inadequate diversification reduces what economists call the risk-adjusted rate of return. A well-diversified portfolio with an expected return of 6 per cent might be as highly valued as an imperfectly diversified (and therefore riskier) portfolio with an expected return of 8 per cent. Secondly, because these restrictions reduce the benefits of a $401(\mathrm{k})$ contribution, employees may rationally contribute less. This reduces the total tax savings still more.

\section{Can participants circumvent restrictions?}

The investment options for all 401(k) plans are restricted, and in some cases the constraints are rather tight. Many participants complain that the available choices fail to fit their needs. Plan participants can alleviate many of the problems associated with limited investment options by remembering that $401(\mathrm{k})$ investments are only one part of their total portfolio. For example, a company's investment options might not contain a fund with enough exposure to international markets to suit a participant. If so, then he can gain the desired exposure by investing in an international fund held outside of the 401(k) plan. Another participant may find the investments offered to be too risky. In that case, he can reduce his overall risk exposure by holding only safe assets outside the plan. The key is that plan participants can circumvent investment restrictions by tailoring their total portfolio. ${ }^{13}$ By following strategies such as these, employees and employers can regain some of the joint tax savings that might otherwise go uncaptured.

\section{The future}

Experts including Altig and Gokhale ${ }^{14}$ believe that the fundamental structure of DC plans such as $401(\mathrm{k})$ accounts and their close cousins, 403(b), 457, and Roth IRAs, represent the future of retirement savings plans in the USA. They point to two main forces. The first is increasing public dissatisfaction with DB plans, which are demonstrating that ultimately, the risk of funding the promised retirement benefits remains whether that risk is shifted initially from the employee to the corporation or not. One of several examples attracting attention is the recent termination of US Airways Group Inc.'s retirement plan with its pilots. ${ }^{15}$ The growing number of such terminations is placing a strain on the Pension Benefit Guaranty Corporation (PBGC), a US government-sponsored agency that insures 44 million workers' DB retirement plans. In recent testimony before the House Committee on Education and the Workforce, the agency's executive director, Steven Kandarian, said that the PBGC's obligations exceed its assets by about $\$ 5.7 \mathrm{bn}$. The first line of defence against such underfunding would be an increase in the premiums paid by healthy companies. If that proves politically or economically unfeasible, Kandarian said, then US taxpayers could be forced to bail out the PBGC. ${ }^{16}$

The second reason experts believe that DC plans such as 401(k) accounts represent the future of retirement savings in the USA is that the nation's public retirement plan, officially named Old-Age and Survivors and Disability Insurance and commonly known as Social Security, is widely recognised to be unsustainable in its current form. According to Jagadeesh Gokhale, an Economic Advisor at the Federal Reserve Bank of Cleveland, either a 
payroll tax increase (to 17.1 per cent from 12.4 per cent) or a benefit reduction in the order of 25 per cent would have been necessary even as early as 1999 in order to place the programme on sound financial footing. ${ }^{17}$ Gokhale believes that these estimates are, if anything, too small, because they use optimistic estimates of longevity and of growth in labour productivity. Moreover, delays in introducing reforms only exacerbate the problems. Along with David Altig, he proposes augmenting the present system with a privatised system of $401(\mathrm{k})$ pension plans, and phasing out entirely the existing social security programme, beginning with workers older than about 32 years of age. ${ }^{14}$ Such a major political step is more likely to be possible if the voting public becomes more familiar with $401(\mathrm{k})$ plans.

\section{Summary}

Retirement savings in the USA are trending towards DC plans versus DB plans. Dissatisfaction with DB plans and questions regarding the sustainability of social security point to increased interest in 401(k), 403(b), 457 plans as well as Roth accounts. While current legislation has reduced the regulatory differences associated with each plan, the effective risk associated with each depends on the parameters established by the plan sponsors as well as the future tax rates expected by plan participants. To maximise return and minimise risk, retirement savings should be viewed in a total portfolio context. As such, it may be appropriate to combine different plan options, such as not only contributing to an employer-sponsored 401(k) plan but also to a Roth account.

\section{Acknowledgment}

Much of this work was completed while DeGennaro served as a visiting scholar at the Federal Reserve Bank of Atlanta, and he gratefully acknowledges research support from the finance group there. The views expressed here are the authors' and not necessarily those of the Federal Reserve Bank of Atlanta or the Federal Reserve System. Any errors are the authors'.

\section{References}

1 See www.ebri.org/facts/1102fact.htm.

2 Hay Group, Inc. (2002) 'The Hay Benefits Reference Guide', Philadelphia, PA, www.haygroup.com

3 While 401(k), 403(b), and 457 plans, as well as Roth IRAs are discussed in this paper, other retirement and/or savings vehicles exist which have different tax consequences. For example, an alternative to a 403 (b) plan or a 457 plan are 401(a) plans; small business owners may qualify for simple IRAs; and 529 plans are used to save for college expenses.

4 The details of HR 1836, The Economic Growth and Tax Relief Reconciliation Act of 2001 were obtained from www.calpers.ca.gov/employer/cirltrs/ 01cl20007501.pdf.

5 See www.expertplan.com/faq $401 \mathrm{k} /$ general.jsp

6 Information was gathered from http://www.fairmark.com/rothira/roth101.htm.

7 With $401(\mathrm{k})$ and 403(b) plans, normal withdrawals can be taken after the age 59 -and-a-half but must begin by age 70 -and-a-half.

8 See Krishnan, V. S. and Lawrence, S. (2001) 'Analysis of investment choices for retirement: A new approach and perspective', Financial Services Review, Vol. 10, pp. 75-86. They explicitly analyse the choice between a Roth IRA and a deductible IRA. However, because of the similar tax treatment of a deductible IRA and a 401(k) plan, their results also apply when comparing a Roth IRA to a 401(k) plan.

9 Krishnan and Lawrence point out that options embedded in these plans might affect the result. For example, first-time homebuyers may withdraw earnings after five years without taxes.

10 For a discussion regarding diversification across assets see Merton, R. and Samuelson, P. A. (1974) 'Fallacy of the lognormal approximation of optimal portfolio decision making over many periods', Journal of Financial Economics, Vol. 1, No. 1, pp. 67-94, and Samuelson, P. A. (1990) 'Asset allocation could be dangerous to your health', Journal of Portfolio Management, Vol. 16, No. 3, pp. 5-8.

11 Optimal diversification can be determined by, for example, minimising the expected variance of a portfolio $\left(\sigma_{\mathrm{p}}^{2}=\Sigma \Sigma W_{i} W_{j} \operatorname{Cov}_{i j}\right)$ subject to the expected return of the portfolio $\left(E\left(R_{p}\right)=\Sigma W_{i} E\left(R_{i}\right)\right)$.

12 Research regarding substituting diversification across time for diversification assets can be found in Gunthorpe, D. and Levy, A. (1996) 'Optimal growth portfolios reconciling theory and practice', Review of Quantitative Finance and Accounting, Vol. 7, No. 2, pp. 177-186. For a discussion of optimal portfolio construction, see Gunthorpe, D. and Levy, H. (1994) 'Portfolio composition and the investment horizon', 
Financial Analysts Journal, Vol. 50, No. 1 January/February, pp. 51-56.

13 Two examples are: DeGennaro, R. P. (2004) 'Asset allocation and section 529 plans', International Journal of Business, Vol. 9, No. 2, pp. 125-132; and

Domian, D. L. and Racine, M. D. 'Wealth and risk from leveraged stock portfolios', Financial Services Review, Vol. 11, No. 1, pp. 33-46.

14 Altig, D. E. and Gokhale, J. (1997) 'Social security privatization: One proposal', Cato Project on Social Security Privatization, No. 9, 29th May.

15 For more information about US Airways Group
Inc.'s action, see, for example, http://cnnfn.cnn.com/ 2003/03/28/news/companies/usairways.reut/ index.htm.

16 For a discussion of the circumstances surrounding a similar bailout and its cost, see DeGennaro, R. P. and Thomson, J. B. (1996) 'Capital forbearance and thrifts: Examining the costs of regulatory gambling', Journal of Financial Services Research, Vol. 10, No. 3, pp. 199-211.

17 Gokhale, J. (1999) 'Testimony submitted to the US Senate Budget Committee', Washington, DC, 19th January. 